University of Nebraska - Lincoln

DigitalCommons@University of Nebraska - Lincoln

1998

\title{
Bait Preference by the Argentine Ant (Hymenoptera: Formicidae) In Haleakala National Park, Hawaii
}

Paul D. Krushelnycky

U.S. Geological Survey

Neil J. Reimer

Hawaii Department of Agriculture

Follow this and additional works at: https://digitalcommons.unl.edu/entomologyother

Part of the Entomology Commons

Krushelnycky, Paul D. and Reimer, Neil J., "Bait Preference by the Argentine Ant (Hymenoptera: Formicidae) In Haleakala National Park, Hawaii" (1998). Entomology Papers from Other Sources. 64. https://digitalcommons.unl.edu/entomologyother/64

This Article is brought to you for free and open access by the Entomology Collections, Miscellaneous at DigitalCommons@University of Nebraska - Lincoln. It has been accepted for inclusion in Entomology Papers from Other Sources by an authorized administrator of DigitalCommons@University of Nebraska - Lincoln. 


\title{
Bait Preference by the Argentine Ant (Hymenoptera: Formicidae) in Haleakala National Park, Hawaii
}

\author{
PAUL D KRUSHELNYCKY ${ }^{1}$ AND NEIL J. REIMER ${ }^{2}$
}

\begin{abstract}
Environ. Entomol. 27(6): 1482-1487 (1998)
ABSTRACT The Argentine ant, Linepithema humile (Mayr), has proven to be a threat to native arthropod species in Haleakala National Park, Maui, HI, and is also a potential threat to the park's native flora. As it continues to expand its range, an effort has been undertaken to eradicate it, or at the least, control its spread. The lst part of this effort focused on finding a bait carrier for subsequent toxicant-based control tests. A year-long bait preference test was implemented at each of the ant's 2 infestation sites in Haleakala National Park, in which 6 solid baits and 2 liquid baits were assessed for attractiveness and feasibility for large scale control. At both sites, a toxicant-free formulation of Maxforce, a protein-based granular bait made from ground silkworm, Bombyx mori (L.), pupae, and a $25 \%$ sugar water solution were the most attractive baits. Ants took more Maxforce (without toxicant) and sugar water than all other baits, including honey granules and a fish protein bait. Sugar water, however, is difficult to distribute over large natural areas. Maxforce was therefore concluded to be the best bait carrier for toxicant-based control at Haleakala National Park because of its attractiveness and its ease for large scale broadcast dispersal.
\end{abstract}

KEY WORDS Argentine ants, bait preference test, Hawaii, biological invasion, alien species

The Hawailan IsLands is one of only a few areas in the world that possesses no endemic species of ants (Wilson and Taylor 1967). The extreme isolation of the islands, located $>3,000 \mathrm{~km}$ from the nearest continent, has insured that very few colonizers have been able to successfully cross this formidable barrier (Loope and Mueller-Dombois 1989). The resulting biota is highly adapted for the particular conditions and array of species that survived. Because ants were absent from this evolutionary process, nothing with their predatory capability helped shape native arthropod defense mechanisms. The consequent vulnerability of native arthropods to ant predation has been well documented (Perkins 1913, Cole et al. 1992, Gillespie and Reimer 1993).

Today, $>40$ species of ants have been collected in the Hawaiian Islands, and a large percentage of these have become naturalized (Huddleston and Fluker 1968, Reimer et al. 1990). Typically, the effects of alien ants have been limited to sea level and lowland areas of the islands, but the Argentine ant, Linepithema humile (Mayr), differs in that it has become established at higher elevations, and therefore has invaded largely intact natural areas such as Haleakala National Park on Maui (Cole et al. 1992). Not only do these higher elevation populations put $L$. humile into mostly undisturbed native habitat, but they also take it out of the range of other dominant alien ants. Although Haleakala National Park has 2 introduced species of

\footnotetext{
${ }^{1}$ U.S. Geological Survey/Biological Resources Division, Haleakal National Park Field Station, Box 369, Makawao, HI 96768.

${ }^{2}$ Hawaii Department of Agriculture, 701 Ilalo Street, Honolulu, HI
} 96813 . ants in addition to the Argentine ant at this elevation, Cardiocondyla venustula (Wheeler) and Hypoponera opaciceps (Mayr), these are both low-impact, lowdensity species that are rarely observed interacting with L. humile (unpublished data; Fellers and Fellers 1982).

Characterized as an aggressive, polygynous tramp species native to South America, the Argentine ant has proven to be a pest in various areas of the world (Holldobler and Wilson 1990). Economically, much attention has been directed at the Argentine ant because of its homopteran-tending behavior, which prevents effective biocontrol of aphids and scale insects and makes the ant an important agricultural pest (Markin 1968). However, the ant's ability to form large, dense unicolonies and its aggressive behavior have also made it an ecological menace. In virtually every area where it has become established, L. humile has displaced the native ant fauna (Erickson 1971, Tremper 1976, Ward 1987).

In South Africa, Bond and Slingsby (1984) have shown that this results in the disruption of a native ant-plant mutualism and severely decreases seed dispersal and establishment in the fynbos. In Haleakala National Park, Cole et al. (1992) have demonstrated the effects of the ant's presence and predation on the native arthropod fauna, and they have suggested that this could have an impact on native plant reproduction, as some of the affected insects are major pollinators of native plants.

The Argentine ant was 1st recorded in Haleakala National Park in 1967 (Huddleston and Fluker 1968). Despite rather extreme climatic conditions on upper Haleakala, the Argentine ant has been able to persist,

0046-225X/98/1482-1487\$02.00/0 C 1998 Entomological Society of America

This article is a U.S. government work, and is not subject to copyright in the United States. 
reproduce, and expand. In fact, by the mid-1980s, 2 distinct populations have become established at 2 different elevations on Haleakala's upper western slopes (Medeiros et al. 1986, Cole et al. 1992), and by 19951996 the ant had occupied $>450$ ha of the park and surrounding areas.

Due to the advance of the Argentine ant in Haleakala National Park, the Research Division (now a unit of the Biological Resources Division of the U.S Geological Survey) began investigating a control strategy for the pest. Biological control is not considered feasible at present, because no control agents have been identified to date. We have therefore studied toxicants as a possible method for control. Previously, control of the introduced ant Wasmannia auropunctata (Roger) was achieved on Santa Fe Island in the Galapagos using the bait Amdro, a corn-grit granular bait with hydramethylnon as the active ingredient (Abedrabbo 1994). Trophallaxis, the passing of regurgitated food among colony members, is a frequent behavioral practice of the Argentine ant and would allow an attractive bait to be shared with all nest members, both adult and larval stages (Markin 1970a).

Bait preference tests have been conducted for the Argentine ant in the laboratory and in citrus groves in California, and it has often been found to prefer sugar water over all other baits (Gaston and Baker 1984, Baker et al. 1985). Additionally, Forschler and Evans (1994) found that the commercially formulated Maxforce (manufactured by the Clorox Company, Pleasanton, CA), hydramethylnon in a protein-based granular bait made from ground silkworm, Bombyx mori (L.), pupae, was attractive to and effective against the Argentine ant in urban situations in Georgia. The food preferences of the ant in the undisturbed natural areas of Haleakala National Park, however, were unknown. For this reason it was deemed necessary to carry out an on-site bait preference test specific to the Argentine ants on Haleakala.

This article reports on the results of a year-long bait preference test conducted in the field at 2 sites infested with Argentine ants. Its purpose was to determine what types of baits are most attractive to the ants and how this preference might change seasonally. The underlying goal was to find a bait carrier for subsequent control tests using hydramethylnon as the active ingredient, with the criteria that the chosen bait would be practical for large scale broadcast dispersal. For instance, while sugar water has previously been found to be highly attractive to the Argentine ant, this medium would not be very practical for treating large and often fairly inaccessible areas. Six solid baits, including Maxforce without toxicant, were selected for field testing and were provided by the Clorox Technical Center in Pleasanton, CA. Sugar water (and to a lesser extent water) was also included as a gauge against which the attractiveness of the solid baits could be measured.

\section{Materials and Methods}

The bait preference test was carried out from June 1994 to June 1995. The following 8 baits were provided by Clorox and were all formulated without the active ingredient hydramethylnon: (1) Maxforce without toxicant, a granular silkworm protein-based bait with additives; (2) honey granules, a 100\% carbohydrate granular bait formulated from Domino Qwik-Flo Honey; (3) insect protein granules, a granular bait consisting of ground silkworm pupae; (4) honey doughy bait, a $100 \%$ carbohydrate bait with a doughy consistency, Combat ant formula 13010; (5) high protein doughy bait, a $100 \%$ protein bait with a doughy consistency, Maxforce ant formula 17750; (6) fish protein bait, a doughy bait consisting of fishmeal in a gel matrix; (7) sugar water, a solution of $25 \%$ (by weight) pure granulated cane sugar; and (8) water.

Two test sites were chosen, 1 in each of the 2 ant populations. The test site for the upper elevation population was located at 2,835 $\mathrm{m}$ in the Kalahaku area, and the test site for the lower elevation population was located at 2,165 m near park headquarters. Both sites had high densities of nesting ants. At each site, 5 replicate stations containing each of the 8 baits were put out for a period of $24 \mathrm{~h}$ during each bait test. Replicates were separated by $3-5 \mathrm{~m}$ and placed on the ground in a random fashion at each site, avoiding lava rock outcroppings and flows.

Replicate stations consisted of 8 plastic petri dishes (each 10 by $35 \mathrm{~mm}$ ) containing the 8 baits placed on the ground $\approx 5 \mathrm{~cm}$ apart in no particular spatial order and covered with an inverted pie pan weighed down with rocks to protect the baits from direct rain, wind, and rodents. Pieces of felt were attached to the inside of the pie pans to prevent moisture from collecting on the aluminum surface and dripping onto the baits. The sugar water and water baits were injected into small cotton balls to prevent spilling during transport and placement. Eight small rectangular holes, $\approx 3 \mathrm{~mm}$ wide, were cut out around the perimeter of the pie pans to allow access to the baits inside. Because of the small stocks of available bait, the amount of solid baits presented in each bait test varied from 0.5 to 2.0 g per petri dish, depending on time of year and corresponding demand by the ants. Amount of liquid baits presented remained consistent at $2.0 \mathrm{ml}$ per petri dish for each bait test.

Each of the 2 test sites also had a corresponding control site, located just outside the range of each ant population. The purpose of the controls was to measure the effects of weather conditions on the weight of each type of bait over the 24-h test period. Control sites were chosen in locations as near as possible to the test sites and had identical set ups (except the holes around the perimeter of the pie pans were covered with mesh screen), with 5 replicates of each of the 8 baits. Each bait test therefore had 4 sites ( 2 test and 2 control) and 20 replicates ( 5 at each site) of each of the 8 baits, for a total of 160 individual petri dishes per test. 
Table 1. Amount of bait taken (grams) by ants per 24-h period, averaged for all replicates in all bait preference tests

\begin{tabular}{|c|c|c|c|c|}
\hline Bait & Bait taken & $n$ & Bait taken & $n$ \\
\hline Maxforce & $0.78 \pm 0.06 a$ & 80 & $0.31 \pm 0.04 \mathrm{a}$ & 73 \\
\hline Honey granules & $0.27 \pm 0.04 \mathrm{~b}$ & 79 & $0.06 \pm 0.01 \mathrm{c}$ & 78 \\
\hline Insect protein granules & $0.16 \pm 0.02 \mathrm{~b}, \mathrm{~d}$ & 79 & $0.11 \pm 0.02 \mathrm{~b}$ & 74 \\
\hline Honey doughy bait & $0.08 \pm 0.01 c$ & 80 & $0.01 \pm 0.00 \mathrm{~d}$ & 76 \\
\hline Sugar water & $0.70 \pm 0.06 \mathrm{a}$ & 80 & $0.18 \pm 0.03 \mathrm{a}$ & 78 \\
\hline Water & $0.19 \pm 0.03 \mathrm{c}$ & 80 & $0.06 \pm 0.01 c$ & 78 \\
\hline
\end{tabular}

Means in the same column followed by the same letter are not significantly different $(t$-test; $P<0.05)$.

Baits were weighed, placed in the field in the morning, collected $24 \mathrm{~h}$ later and weighed again. We attempted to minimize variation in weather conditions by placing baits out only on warm sunny days. Due to highly unpredictable weather on upper Haleakala, however, conditions occasionally changed throughout the day or night of the bait tests. This process was repeated every $2-4 \mathrm{wk}$ over a period of $1 \mathrm{yr}$, for a total of 16 bait preference tests. Mean changes in the weights of the control baits (for each type of bait) were added or subtracted to the changes in weight that occurred in the 5 corresponding test bait replicates for each site and each bait test. Weather effects on the weights of each type of bait were thus eliminated, resulting in the weight of bait taken by ants. Bait test data were subsequently normalized with the square-root transformation and compared using an $F$ test to check for homogeneity of variances. Because variances were often heterogeneous, analysis of variance (ANOVA) was not used. Means were compared either with a $t$-test assuming equal variances or a $t$-test assuming unequal variances.

\section{Results}

Bait test results from the lower elevation ant population $(2,165 \mathrm{~m})$ revealed that Maxforce (without toxicant) and sugar water were by far the most popular baits (Table 1). Comparison of the mean amount of Maxforce (without toxicant) taken with the mean amount of sugar water taken indicated that this difference was not significant $(t=1.09, P>0.05)$. In contrast, much more Maxforce (without toxicant) was taken compared to the 3rd most popular bait, honey granules $(t=6.81, P<0.001)$.

Similarly, analysis of the upper elevation bait test data indicated that the difference between the mean amount of Maxforce bait (without toxicant) taken and the mean amount of sugar water taken was not significant $(t=0.20, P>0.05)$, while the difference in mean amount of bait taken between Maxforce (without toxicant) and the 3rd most popular bait, insect protein granules, was highly significant $(t=3.98, P>$ 0.001 ). Thus, at both the upper and lower elevation, the amount of Maxforce bait (without toxicant) taken by ants was significantly greater than all other baits except sugar water.
The amount of bait removal for most of the baits was seasonal in nature. At the lower elevation, Maxforce (without toxicant) removal was highest from midMarch to October (Fig. 1), and at the upper elevation from mid-March to late August (Fig. 2). The sugarbased baits demonstrated a similar seasonal pattern. Sugar water removal remained high until mid-November at the lower elevation (Fig. 1), but only until August at the higher elevation (Fig. 2). The honey granular bait was consumed much more at the lower elevation (Fig. 1), competing well with the Maxforce bait (without toxicant) during the summer of 1994 . Both populations showed a small increase in uptake of the honey granules in November of 1994, somewhat later than the peak period of uptake of the toxicantfree Maxforce bait (Figs. 1 and 2).

\section{Discussion}

A year of bait preference tests at the 2 sites of Argentine ant infestation at Haleakala National Park indicated that of the 6 solid baits tested, the Maxforce bait (without toxicant) was most attractive. Maxforce is a granular protein bait consisting mainly of ground-up silkworm pupae and formulated with $0.9 \%$ of the active ingredient hydramethylnon. When formulated without this toxicant, more Maxforce was taken by the ants over the course of the 16 bait tests than any of the other solid baits (Table 1). This was true for both the upper $(2,835 \mathrm{~m})$ and lower $(2,165 \mathrm{~m})$ elevation ant populations. Maxforce (without toxicant) out-performed such potentially attractive baits as honey granules, straight insect protein granules, and fish protein bait. Although it has been found that a blended fermented fish bait is very effective for attracting Argentine ants to pitfall traps and other monitoring stations at Haleakala, the fish protein bait formulated by Clorox for our bait preference tests was much less attractive, most likely due to loss of freshness and odor in manufacturing.

At both the high and low elevation sites, Maxforce (without toxicant) was not taken in significantly greater amounts than a $25 \%$ sugar water solution. Ants may have taken even more sugar water had it been presented as a standing liquid as opposed to being injected into a cotton ball, but this latter method was deemed more practical because of the difficulty in 


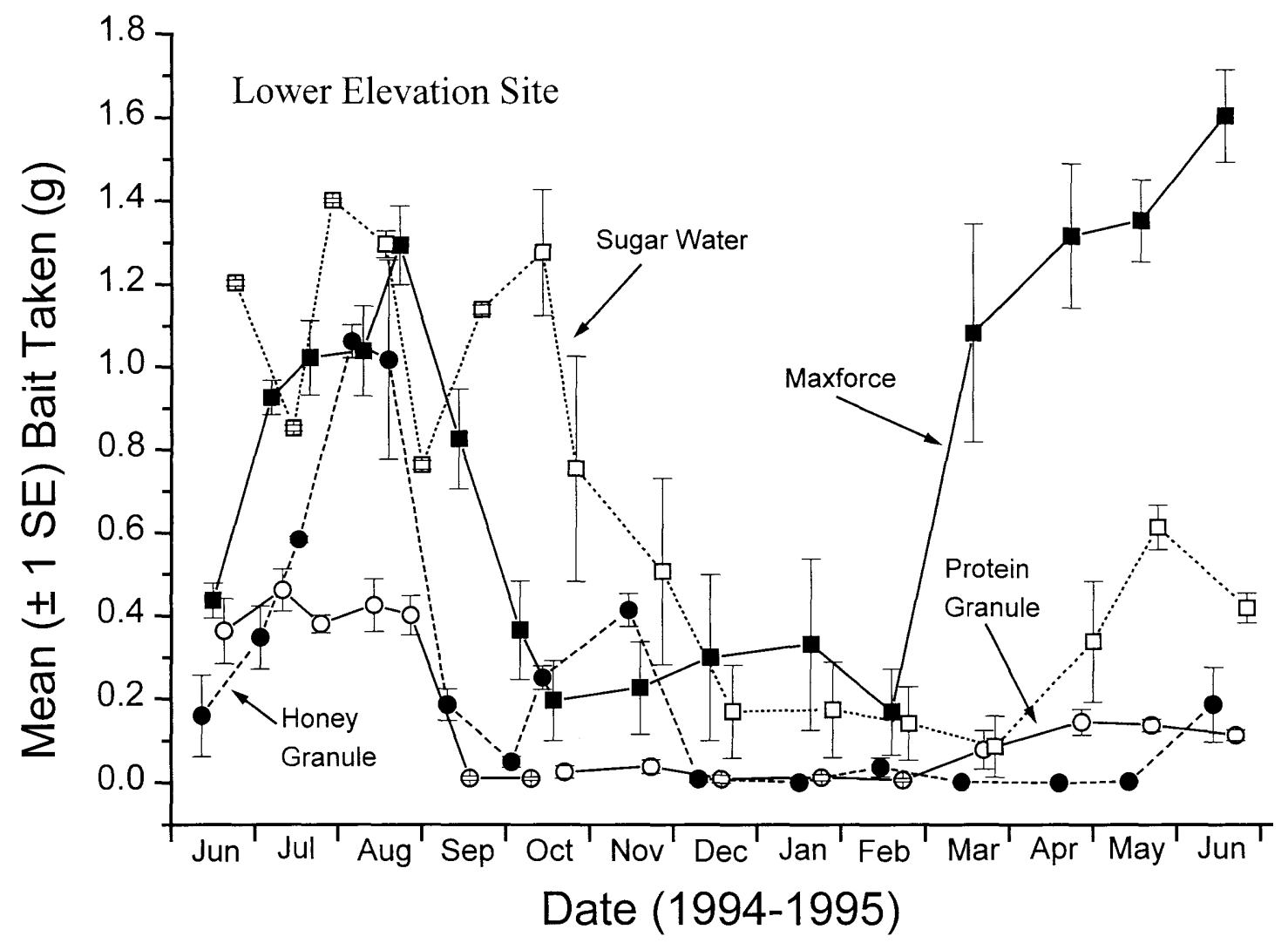

Fig. 1. Mean weights of the 4 most popular baits taken during each bait preference test in the lower elevation ant population ( $\mathbf{\square}$, Maxforce; Honey Granule; $\bigcirc$. Protein Granule; $\square$, Sugar Water). Bars $=1 \mathrm{SE}$.

reaching the field sites. In addition, measured weights of sugar water removed by ants are probably more accurate reflections of the amount of bait consumed by the ants, because some of the solid baits may have been removed but left unconsumed. It has also been speculated that liquid baits may be more effective at delivering toxicant to the ants than solid baits. Unfortunately, liquid baits are not very compatible with the type of control methods considered necessary at Haleakala National Park at this time. With this in mind, Maxforce (without toxicant) stands alone among the solid baits as having the greatest attractiveness, comparable to sugar water, at Haleakala.

Amount of baits taken by the ants typically displayed a strong seasonal trend (Figs. 1 and 2). This was true for all popular baits, including the toxicant-free Maxforce bait. Seasonal variation in the amount of bait taken can be linked to several trends-seasonal variation in weather conditions, seasonal variation in colony size, and seasonal variation in food type preference. These trends are correlated with the yearly life cycle of the Argentine ant.

At Haleakala the ant's main reproductive period lasts from spring until fall, and appears to peak in early summer (P.D.K., unpublished data). In the spring, reproduction increases, signaled by the appearance of the 1st large batch of worker brood. This brood gen- erally precedes and helps provide for the intense sexual brood production that follows (Markin 1970b). Although males can be found in small numbers yearround, these sexual forms are most abundant from late March to September. The production of new queens usually occurs shortly after heavy male production is under way (Markin 1970b), but this caste is difficult to observe in the field and therefore is a less reliable indicator of annual reproductive cycle status. After fall, sexual production drops off sharply, as does worker production, and nest size decreases during the winter months.

A decline in the amount of Maxforce (without toxicant) taken in winter months can be attributed in part to the decrease in nest size and to colder temperatures, which influence foraging rates (although all efforts were made to conduct the bait tests only on warm sunny days). However, it can also be explained by a shift in food type preference and requirements. Although colonies need protein year-round to provide for the development of larvae and the nourishment of the queens, this need increases tremendously in the spring and summer when egg production and larval growth explode. This pattern is reflected in the trends of Maxforce (without toxicant) consumption (Figs. 1 and 2). Consumption of honey granules and sugar water also generally fit this trend, because these are 


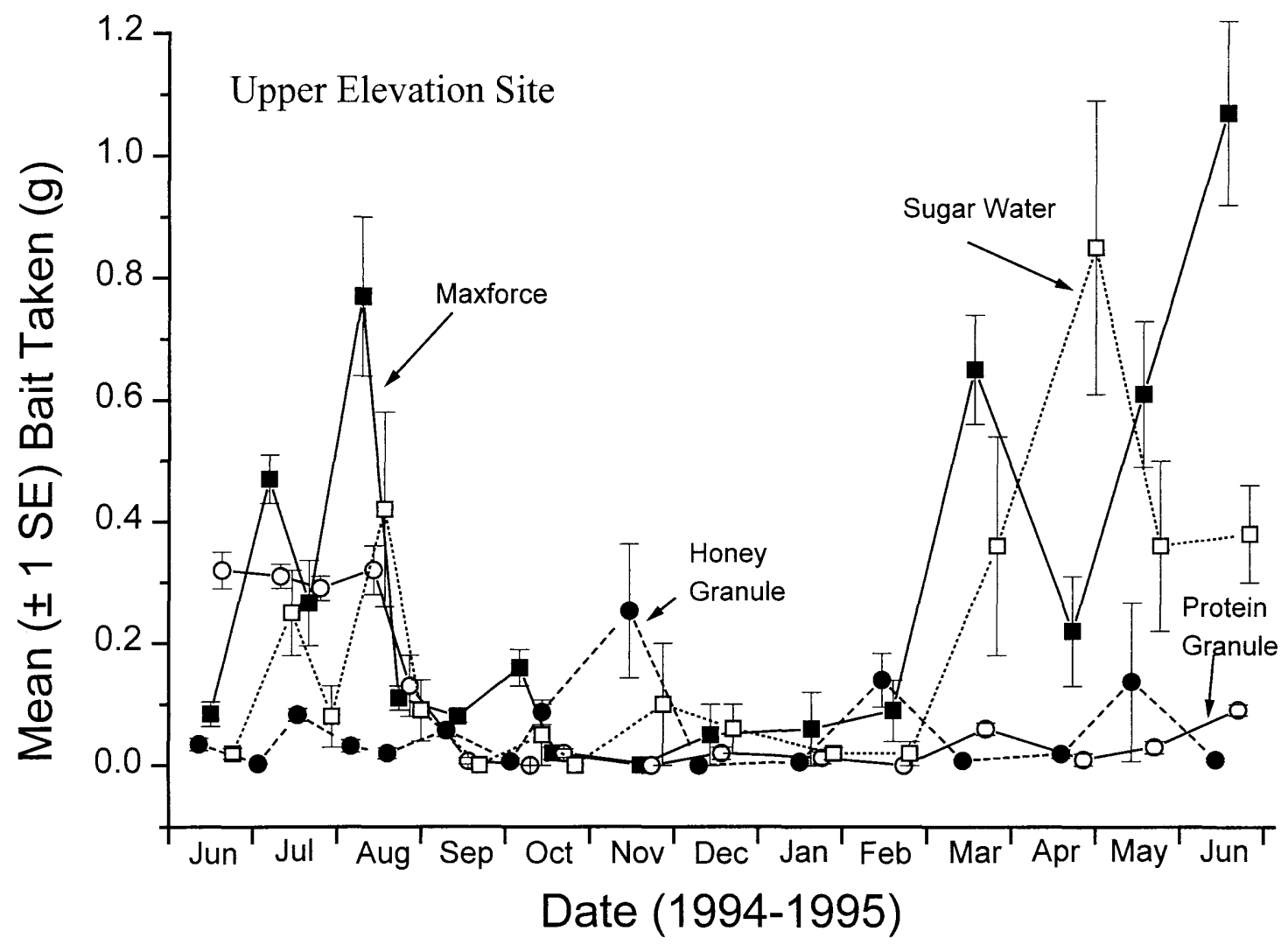

Fig. 2. Mean weights of the 4 most popular baits taken during each bait preference test in the upper elevation ant population ( $\mathbf{\square}$, Maxforce; , Honey Granule; $\mathrm{O}$, Protein Granule; $\square$, Sugar Water). Bars $=1 \mathrm{SE}$.

important energy sources needed to fuel the many workers foraging for food and tending to the brood and queens. It is interesting that sugar-based bait consumption exceeded protein-based bait consumption in the late fall (Figs. 1 and 2). This shift in food type preference may be a result of brood production being low while the remaining workers were still searching for an easy and efficient energy source.

Because the effectiveness of the hydramethylnon toxicant relies heavily on bait retrieval and sharing within the nest, it is critical that any control effort implemented maximizes bait preference and ant foraging levels. In this study, toxicant-free Maxforce proved to be the most attractive solid bait for ant populations at both upper and lower elevation sites at Haleakala. Its attractiveness was comparable to sugar water, and this bait also meets the criteria of feasibility for large scale broadcast dispersal. It was therefore chosen as the bait carrier for our experimental control efforts.

\section{Acknowledgments}

We thank, first and foremost, Art Medeiros (U.S. Geological Survey/Biological Resources Division) and Lloyd Loope (USGS/BRD) for laying the groundwork for this study and bringing concern about the Argentine ant's presence to the forefront. In addition, they provided much support and advice throughout the project. Also of critical importance, Lisa Blum, Ted Shapas, and other staff at the Clorox Technical Center contributed funds, Maxforce and other baits, and generously donated time and expertise to our efforts. We also thank Philip Thomas (USGS/BRD) for his help in database design and general computer assistance. Much advice and assistance was also provided in statistical analysis by IIelen Baker, Anne Brasher and Ellen Van Gelder while working at the USGS/BRD Haleakala National Park Field Station.

\section{References Cited}

Abedrabbo, S. 1994. Control of the little fire ant, Wasmannia auropunctata, on Santa Fe Island in the Galapagos Islands, pp. 219-227. In D. F. Williams [ed.], Exotic ants: biology, impact, and control of introduced species. Westview, Boulder, CO.

Baker, T. C., S. E. Van Vorhis Key, and L. K. Gaston. 1985. Bait-preference tests for the Argentine ant (Hymenoptera: Formicidae). J. Econ. Entomol. 78: 1083-1088.

Bond, W., and P. Slingsby. 1984. Collapse of an ant-plant mutualism: the Argentine ant (Iridomyrmex humilis) and myrmecochorous proteaceae. Ecology 65: 1031-1037.

Cole, F. R., A. C. Medeiros, L. L. Loope, and W. W. Zuehlke. 1992. Effects of the Argentine ant on arthropod fauna of 
Hawaiian high elevation shrubland. Ecology 73: 13131322.

Erickson, J. M. 1971. The displacement of native ant species by the introduced Argentine ant Iridomyrmex humilis Mayr. Psyche 78: 257-266.

Fellers, J.H., and G. M. Fellers. 1982. Status and distribution of ants in the Crater District of Haleakala National Park. Pac. Sci. 36 427-437.

Forschler, B. T., and G. M. Evans. 1994. Argentine ant (Hymenoptera: Formicidae) foraging activity response to selected containerized baits. J. Entomol. Sci. 29: 209-214.

Gaston, L. K., and T. C. Baker. 1984. Toxic bait to control Argentine ant field tested. Citrograph 69: 188.

Gillespie, R. G., and N. Reimer. 1993. The effect of alien predatory ants (Hymenoptera: Formicidae) on Hawaiian endemic spiders (Araneae: Tetragnathidae). Pac. Sci. 47: 21-33.

Holldobler, B., and E. O. Wilson. 1990. The ants. Belknap/ Harvard University Press, Cambridge, MA.

Huddleston, E. W., and S. Fluker. 1968. Distribution of ants species of Hawaii. Proc. Hawaii. Entomol. Soc. 20: $45-69$.

Loope, L. L., and D. Mueller-Dombois. 1989. Characteristics of invaded islands, with special reference to Hawaii, pp. 257-280. In J. Drake, H. Mooney, F. di Castri, R. Groves, F. Kruger, M. Rejmanek, and M. Williamson [eds.], Biological invasions: a global perspective. Wiley, Chichester, UK.

Markin, G. P. 1968. Nest relationship of the Argentine ant, Iridomyrmex humilis (Hymenoptera: Formicidae). J. Kans. Entomol. Soc. 41: 511-516.

Markin, G. P. 1970a. Food distribution within laboratory colonies of the Argentine ant, Iridomyrmex humilis (Mayr). Insectes Soc. 17: 127-158.
Markin, G. P. 1970b. The seasonal life cycle of the Argentine ant, Iridomyrmex humilis (Hymenoptera: Formicidae), in southern California. Ann. Entomol. Soc. Am. 63: $1238-1243$.

Medeiros, A. C., L. L. Loope, and F. R. Cole. 1986. Distribution of ants and their effects on endemic biota of Haleakala and Hawaii Volcanoes National Parks: a preliminary assessment, pp. 39-52. In Proceedings, Sixth Conference in Natural Sciences, 10-13 June 1986, Hawaii Volcanoes National Park. Cooperative National Park Resources Studies Unit, Department of Botany, University of Hawaii, Honolulu, HI.

Perkins, R.C.L. 1913. Fauna Hawaiiensis. Cambridge-atthe-University Press, Cambridge, England.

Reimer, N. J., J. W. Beardsley, and G. Jahn. 1990. Pest ants in the Hawaiian Islands, pp. 40-50. In R. K. Vander Meer, K. Jaffe, and A. Cedeno [eds.], Applied myrmecology: a world perspective. Westview, Boulder, CO.

Tremper, B. S. 1976. Distribution of the Argentine ant, Iridomyrmex humilis Mayr, in relation to certain native ants of California: ecological, physiological, and behavioral aspects. Ph.D.dissertation, University of California Berkeley.

Ward, P. S. 1987. Distribution of the introduced Argentine ant (Iridomyrmex humilis) in natural habitats of the lower Sacramento Valley and its effects on the indigenous ant fauna. Hilgardia 55: 1-16.

Wilson, E. O., and R. W. Taylor. 1967. The ants of Polynesia. Pac. Insects Monogr. 14

Received for publication 1 April 1998; accepted 3 September 1998 